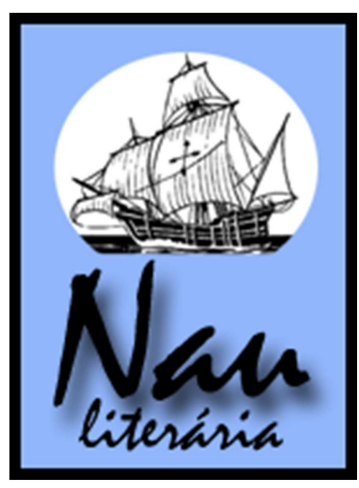

Nau Literária: crítica e teoria de literaturas • seer.ufrgs.br/NauLiteraria

ISSN 1981-4526• PPG-LET-UFRGS • Porto Alegre • Vol. 07 N. $01 \bullet$ jan/jun 2011

Dossiê: literaturas africanas de LP

\title{
Angola, Moçambique e Cabo Verde: uma introdução à prosa de ficção da África lusófona
}

Maurício Silva*

Resumo: O presente artigo procura analisar a relação entre identidade cultural e consciência nacionalista nas literaturas africanas lusófonas, principalmente considerando as perspectivas estéticas (Sartre) e moral (Marcuse).

Palavras-chave: Literatura Africana Lusófona; identidade cultural; consciência nacionalista; moral; estética
Abstract: The presente article analyses the relations between cultural identity and reform and nationalism in the Portuguese African Literatures. Besides, it focuses those relations both from the aesthetic (Sartre) anda moralistic (Marcuse) perspectives.

Keywords: Portuguese African Literature; cultural identity; nationalism; moralistism; aesthetics.

\section{Introdução}

Desde a década de 1970, as relações entre Portugal e suas ex-colônias sofreram profundas alterações, a partir das quais se promoveu uma revisão dos conceitos que lhes davam sustentação pragmática e ideológica, sobretudo no que se refere à tão debatida questão colonial. Atualmente, quando se discute abertamente as diretrizes e os resultados preliminares do amplo processo de globalização por que passam todas as nações politicamente organizadas, faz-se ainda mais necessário uma amplificação de nossas perspectivas culturais, redirecionando nossos interesses para realidades pouco contempladas pelas abordagens culturalistas tradicionais.

Nesse contexto, destaca-se a necessidade de retomada das relações político-culturais entre os países de língua portuguesa, relevando o aspecto peculiar de suas respectivas culturas. Sob essa ótica, compreende-se a importância assumida, no presente momento, pelo estudo das literaturas africanas de expressão portuguesa, por meio do qual se busca promover uma aproximação entre culturas que, historicamente, sempre estiveram unidas.

A importância e reconhecimento que, a par disso, a literatura africana em português tem merecido da crítica nacional e internacional vem mostrar a pertinência de se estudar e

\footnotetext{
* Pós-Doutorado em Letras Clássicas e Vernáculas. Professor e coordenador da Pós-Graduação em Educação (Universidade Nove de Julho).
} 
divulgar com mais afinco e empenho alguns de seus mais representativos nomes, abordando não apenas aspectos que revelam a competência estética de seus autores em criar uma literatura autônoma e original, mas também que demonstrem como essa literatura pode interagir com todo o processo de construção da identidade cultural africana, equacionando, assim, as contradições que foram historicamente implantadas por um sistema de colonização.

Nesse sentido, o presente artigo tem como objetivo abordar a produção ficcional de alguns dos principais escritores lusoafricanos, analisando genericamente temas e motivos presentes em suas obras, tanto do ponto de vista sócio-histórico quanto do ponto de vista estético-literário. Com efeito, estudar a produção ficcional destes autores é compreender como se organiza, no espaço cultural lusoafricano, a concepção de mundo dos povos que ali vivem, bem como sua relação com a própria língua portuguesa - que, aliás, resulta não apenas de um processo de criação lexical / rearticulação morfossintática do idioma, mas também da adoção de uma dicção próxima de registros linguísticos dos grandes centros urbanos -, além de refazer o caminho histórico e cultural destas nações por meio de uma interação entre a literatura e a realidade local.

\section{Angola}

Tendo conhecido uma primeira fase marcada pela expressão tipicamente colonial e nativista (com escritores como José da Silva Maia Ferreira, autor de Espontaneidade da Minha Alma, 1849; e Pedro Félix Machado, autor de O Filho Adulterino, 1892), a literatura angolana atinge um período marcado pela expressão anticolonialista (com Cordeiro da Mata, autor de Delírios, 1877; e Alfredo Troni, com a célebre novela Senhora Viúva, 1882/1973). A fase seguinte já traz a contribuição de uma literatura pré-independentista, com o neo-realismo de um Assis Júnior (com O Segredo da Morta, 1936) e um Castro Soromenho (com Noite de Angústia, 1939; Homens sem Caminho, 1942; Calenga, 1945; Terra Morta, 1949). A literatura angolana atinge o auge de sua produção literária com uma fase que, por mais de um motivo, pode ser chamada de independente, período que se inicia sob os auspícios de um nacionalismo localista, inspirador da famosa Antologia dos Novos Poetas de Angola (1950) e, uma década depois, de poesias como as de Agostinho Neto (Poemas, 1960; Sagrada Esperança, 1974), Viriato da Cruz (Poemas, 1961), Antonio Jacinto (Poemas, 1961), Costa Andrade (Terra das Acácias Rubras, 1961), Alexandre Dáskalos (Poemas, 1961) e outros.

Poesia da melhor qualidade que se criou em Angola, essa produção concilia sentimento nacionalista e expressão lírica, buscando assim equacionar as contradições historicamente criadas por séculos de exploração colonial. Nos dizeres de Maria Aparecida 
Santilli,

o trabalho de construção poética consiste, assim, em avançar no re-conhecimento da identidade, pelo tatear em busca de referir-se devidamente ao referente africano/angolano, tal como este deveria estar em realidade ligado com outros. O processo poético corrige, então, a convenção cristalizada de África estática - que o poema questiona -, a partir do plural africano proposto, em oposição, portanto, ao superado conceito de continente histórica ou culturalmente monolítico. (SANTILLI, 1985b, p. 66).

No que diz respeito à prosa, além do já citado Castro Soromenho, a literatura angolana atinge sua maturidade com as obras de Arnaldo Santos (Quinaxixe, 1965), José Luandino Vieira (Luuanda, 1964; A Vida Verdadeira de Domingos Xavier, 1974; Nós, os do Makulusu, 1975; João Vêncio: os seus Amores, 1979), Mendes de Carvalho / Uanhenga Xitu (Mestre Tamoda, 1974; Bola com Feitiço, 1974; Manana, 1974; Maka na Sanzala, 1979), Arthur Maurício Pestana dos Santos / Pepetela (As Aventuras de Ngunga, 1976; Mayombe, 1980; Yaka, 1984; A Geração da Utopia, 1992), Boaventura Cardoso (Dizanga dia Muenhu / A Lagoa da Vida, 1977), Jofre Rocha (Estórias de Musseque, 1976) e muitos outros.

Trata-se de uma produção, nos dizeres certeiros de Pires Laranjeira, em que a expressão literária

combate o exotismo sob todas as formas, quer se apresente recuperando narrativas tradicionais, quer utilize ritmos e segmentos significantes emprestados das culturas populares, empenhandose na desmitificação desses pontilhados culturais, libertando-os do seu significado de fetiche turístico e cartaz ilusioriamente localista, o regionalismo sobrevive não em esteriótipos, frases feitas ou tipos de personagens, mas pelo labiríntico da escrita e da acção, pela mistura plurilingüística, pelo preenchimento mnemônico dos espaços imaginários e oníricos dos leitores desapropriados de ser e pátria. (LARANJEIRA, 1985, p. 13).

Essa é, certamente, uma opinião que define praticamente toda a literatura angolana de, pelo menos, meados do século XX até os dias atuais. Se quisermos, contudo, compreender melhor essa produção, convém aproximarmos mais o foco de nossa análise e observarmos mais de perto a ficção de alguns de seus maiores autores. Três grandes nomes da literatura angolana contemporânea, representando três fases distintas, podem nos oferecer uma visão mais completa e, ao mesmo tempo, mais profunda dessa produção: José Luandino Vieira (décadas de 1960/1970), Pepetela (décadas de 1970/1980) e José Eduardo Agualusa (décadas de 1980/1990).

Luandino Vieira, autor premiado e consagrado internacionalmente, torna-se, pelo menos desde Luuanda (1964), expressão máxima da literatura angolana, tendo ainda participado ativamente da vida política de seu país, tanto como militante clandestino nas lutas anticolonialistas quanto como membro do MPLA. Sua celebrada produção - que inclui obras como A Cidade e a Infância (1960), A Vida Verdadeira de Domingos Xavier (1961), Luuanda 
(1964), Velhas Estórias (1974), No Antigamente, na Vida (1974), Nós, os do Makulusu (1975), Macandumba (1978), João Vêncio e os seus Amores (1979) etc. - possui inegável valor estético-literário, além de desempenhar, sobretudo no contexto em que foi criada, relevante papel político-social, inserindo-se ainda - pelos achados criativos e pelas ousadias estilísticas - numa moderna tradição de transgressão linguística.

É essa transgressão de natureza linguajeira, portanto, que dita o trabalho de reescritura da Língua Portuguesa levada a termo por Luandino Vieira (SILVA, 2007) e incidindo diretamente sobre a constituição de uma consciência nacionalista, já que a nova linguagem forjada no âmbito de sua produção literária acaba servindo de substrato ideológico e expressivo ao conceito de angolanidade. Com razão já se disse mais de uma vez que a linguagem empregada pelo autor de Luuanda confere à cultura nacional uma identidade própria, já que

Luandino dá a imagem da sociedade angolana em processo de simbiose ou de influências, onde traços de diferentes culturas se atritam e disputam primazias. Um desses traços, a fala, isto é, o quimbundo ou o português dialetizado, por oposição à língua, o português de Portugal, funciona também como código de identificação no conjunto de fatores que passam a caracterizar a angolanidade. (SANTILLI, 1985, p. 18)

Do ponto de vista dos temas e motivos literários representados em sua obra, destacase, sem dúvida alguma, a temática social, sempre reconstruída a partir da ótica literária, com a exposição dos conflitos raciais e a exploração da dicotomia entre civilização (europeus) e barbárie (africanos), temas construídos a partir de uma visão deliberadamente pessimista da sociedade. Não se trata, evidentemente, de um pessimismo desalentador, que enrijece a vontade de luta e mudança, mas um pessimismo aliciante, que instiga à revolta contra as distorções sociais apontadas na trama de suas efabulações. Não obstante essa temática densa, de uma ideologia cerrada, suas principais conquistas estéticas concentram-se no campo da estilística, já que com a prosa ficcional de Luandino Vieira a literatura angolana atinge seu ponto máximo de expressão artística, sobretudo no que diz respeito ao tratamento linguisticamente inovador do texto literário. Tal inovação pode ser verificada tanto no âmbito sintático, levando o autor a promover verdadeira ruptura no encadeamento oracional do português, quanto nos âmbitos morfológico - com sua indefectível criatividade lexical - e fonológico, em que o emprego deliberado de uma linguagem coloquial e o uso de artifícios próprios da oralidade, incorporados ao texto escrito, fazem de suas transgressões linguísticas uma ocorrência esteticamente programática.

Autor de obras de repercussão internacional, Pepetela (pseudônimo de Arthur Maurício Pestana dos Santos), ao lado de Luandino Vieira, redime a literatura angolana da 
condição de literatura periférica e colonial para alçá-la à de expressão artística de valor universal. Com obras como Yaka (1984) ou A Geração da Utopia (1992), por exemplo, Pepetela consegue exprimir literariamente uma realidade onde conflitos raciais e outras formas de comprometimentos sociais são trazidos à tona, revelando a complexa e traumática herança da colonização do continente africano.

Com desprendimento e paixão, Yaka narra o conturbado relacionamento entre Angola e os colonizadores portugueses, revelando, além de tudo, uma intensa consciência histórica por parte do autor. A linguagem empregada para levar adiante essa sua denúncia procura, contudo, mesclar - como é comum à literatura de expressão africana pós-independência, a exemplo do que fez maximamente Luandino Vieira - a prosódia do colonizador (no caso, a língua portuguesa) e a do colonizado (no caso, o quimbundo), dando assim aos fatos narrados um maior realismo e, concomitantemente, elevando a obra à categoria dos grandes livros da cultura ocidental, da qual a língua portuguesa inegavelmente faz parte.

Se em Yaka a presença da exploração comercial - emprego de mão de obra escrava, comércio protecionista e monopolizado - e da supremacia etnocultural portuguesa aparece de forma algo restrita, o mesmo não se pode dizer do racismo enquanto ideologia que fundamenta as relações sociais presentes no romance. Esse tema, ao contrário, conforma a obra por inteiro, fazendo surgir na sociedade angolana toda sorte de injustiças, como a explícita tentativa de embranquecimento da população, levada a cabo pelos colonizadores Tal procedimento revela, no plano da narrativa, um maquiavélico projeto de erradicação da memória étnica das populações locais, submetidas, assim, a um incondicional processo civilizatório.

Discriminações mais explícitas e brutais surgem ao longo de todo o romance, exprimindo ora um sentimento de supremacia racial, que acaba por tomar conta dos colonos brancos, ora um desprezo propriamente dito pelos negros. E esses são apenas alguns exemplos do alcance da temática do racismo na obra de Pepetela, sobrepondo-se mesmo a outros temas que aparecem ao longo da narrativa: o desgosto dos colonos, quase que obrigados a viver sob o peso de um eterno desterro; as constantes ameaças que estes mesmos colonos sentem diante de uma realidade que, vez por outra, lhes parece completamente hostil etc. Somando isso tudo, Yaka resulta num dos mais contundentes relatos do sofrimentos do povo angolano e numa das mais expressivas obras de literatura em língua portuguesa que o final do século XX concebeu.

Já em A Geração da Utopia, o que se percebe é uma bem-acabada tentativa de resgatar a história de Angola por meio da prosa de ficção. Romance histórico, no sentido mais amplo 
do termo, trata-se, ideologicamente falando, da busca de um sentido para a nacionalidade angolana e de uma razão para a consolidação de uma identidade cultural. Tematizando a crise do sistema colonial, mas sem fazer concessões a ideologias de direita e de esquerda, a projetos colonialistas ou anticolonialistas, a vencedores e a vencidos, Pepetela nos oferece um amplo retrato da história angolana, da década de 1960 até a de 1990, dividindo sua história, cronologicamente, da gestação (década de 1960) à falência (década de 1990) de um ideal utópico de construção de uma nação, sem deixar de passar por sua implantação (década de 1970) e consolidação (década de 1980).

Buscando, do ponto de vista literário, a dinamização espacial - isto é, elegendo o espaço como personagem - e a dinamização temporal - ou seja, elevando o tempo à categoria de elemento estruturador da narrativa -, A Geração da Utopia é uma das grandes obras de Pepetela, cuja produção conta ainda com romances como As Aventuras de Ngunga (1973), Mayombe (1980), Parábola do Cágado Velho (1997) e outras. Com efeito, se o tempo condiciona a subdivisão desse romance em capítulos, construídos a partir da divisão do enredo em quatro décadas distintas, o espaço ganha foros de personagem central no livro, aparecendo sob a forma diferenciada de espaço urbano (primeiro capítulo), floresta (segundo capítulo), litoral (terceiro capítulo), e espaço urbano novamente (quarto capítulo). De inspiração neo-realista (apoiando-se, portanto, tanto no neo-realismo português quanto no realismo social brasileiro de 30), trata-se, como já se afirmou uma vez, do "despertar da consciência coletiva de um povo pela ênfase dada ao social”. (SANTOS, 2001, p. 15).

José Eduardo Agualusa é um dos autores contemporâneos mais admirados pela crítica especializada e pelo leitor comum. Desde suas primeiras obras, narra acontecimentos relacionados não apenas á história recente de Angola, mas também ao vasto imaginário do continente africano, com sua diversidade cultural e suas ricas manifestações locais.

Em A Conjura (1989), por exemplo, história que tem como cenário a cidade de Luanda em 1880, discutem-se questões relacionadas à colonização portuguesa e à independência de Angola, num contexto em que se planeja uma revolta (conjura) independentista, frustrada pelo barbeiro Jerónimo Caninguili. Mesclando humor e crítica, o romance confere à linguagem um papel fundamental na composição da narrativa, trabalhando não apenas aspectos relacionados à oralidade, mas também redes intertextuais que fazem do texto um largo cenário cultural. Mas é em A Feira dos Assombrados e Outras Estórias Inverossímeis (1992) que Agualusa exercita com mais competência e ousadia faces da mística africana, misturando história e ficção, com uma narrativa de cunho memorialístico em que verdade e mentira se entrecruzam constantemente. 
Livro que rapidamente ganhou repercussão dentro e fora do continente africano, Estação das Chuvas (1996) é obra em que prevalece o cunho documental, inspirada na história de Angola, mas mais uma vez mesclando fatos reais e ficcionais, caráter híbrido que só se adensa com a utilização de expedientes aparentemente avessos à narrativa ficcional (como entrevista, notas de rodapé etc.) Revisitando ficcionalmente o movimento pela independência de Angola, Agualusa cria uma obra que - não fosse a ousadia estrutural e a ironia do tonos narrativo - enquadrar-se-ia na mais pura tradição da literatura militante, que vai, em Angola, da poesia de Agostinho Neto à prosa de Pepetela. Mas o livro mais famoso de Agualusa seria publicado no ano seguinte: com o romance epistolar Nação Crioula (1997), o romancista angolano levaria ao paroxismo os artifícios intertextuais, bem como seu já tradicional empenho em "confundir" realidade e ficção. Dialogando direta ou indiretamente com algumas célebres obras da literatura em língua portuguesa, Nação Crioula afirma-se como o desfecho de um longo percurso de construção de uma identidade marcada pela miscigenação e pela consciência crítica das relações entre os continentes americano, europeu e africano.

Depois da publicação de obras que tornaram Agualusa escritor de renome dentro da literatura angolana, outras obras "menores" vieram se somar ao seu legado literário já consolidado, como Fronteiras Perdidas (1999), pequenos contos espirituosos, de um humorismo ágil e irônico; e A Substância do Amor e Outras Crônicas (2000), narrativas rápidas, caracterizadas pelo inesperado, pelo insólito das situações e seus desdobramentos. Do mesmo ano que este último, Um Estranho em Goa (2000) já é romance de maior fôlego narrativo, levando o autor a transformar uma experiência concreta (sua estada em Goa, região da Índia) em experiências subjetivas, internalizadas, que nascem das impressões colhidas do contato com uma realidade totalmente nova e diferente. De uma maneira um pouco mais trágica e um pouco mais realista que em outros livros, nessa obra Agualusa aborda a questão da identidade sob o prisma dos descendentes portugueses que vivem em Goa, dando ao tema um caráter mais político, mas ao mesmo tempo lírico e reflexivo, o que levaria o narrador, por exemplo, a concluir, entre outras máximas contidas no livro, que "viajar é perder pessoas". (AGUALUSA, 2001, p. 151)

Dois grandes romances - considerando a pouca repercussão de obras posteriores, como o poético e sarcástico Manual Prático de Levitação (2005) e o instável As Mulheres de meu Pai (2007) - viriam coroar a trajetória de sucesso de José Eduardo Agualusa. O Primeiro deles, é o impactante $O$ Ano em que Zumbi tomou o Rio (2002), narrativa que se passa no Rio de Janeiro, com personagens brasileiros e angolanos, construída em capítulos que funcionam 
como se fossem pequenas cenas cinematográficas simultâneas ou que se sucedem, criando uma perspectiva fragmentada, mas que consegue se articular numa unidade temática. A obra discute mais a fundo temas de natureza racial, fazendo dialogar - especialmente nesse quesito - as visões do angolano (Francisco Palmares) e do brasileiro (Jararaca). Sem dispensar o já tradicional artifício do intertexto - pelo contrário, adensando-o -, o autor cria situações de tensão extrema, em que o diferencial pode ser, por exemplo, saber em que lado da guerra se está, levando um dos personagens à conclusão peremptória de que "nunca se esquecem as lições aprendidas na dor". (AGUALUSA, 2002, p. 81).

O outro grande romance, obra máxima dentro da premiada produção de Agualusa, é seu curioso e insólito $O$ Vendedor de Passados (2004). Narrativa mágica - no que este conceito pode conter de fantástico -, trata-se da história de Félix Ventura, nome sugestivo para a atividade da personagem, um vendedor de passados, isto é, um fabricante de árvores genealógicas, fotos de ancestrais, pergaminhos antigos, enfim, tudo o que possa conferir ao cliente um passado nobre. Entre idas e vindas inesperadas, discutem-se não apenas aspectos da história recente de Angola, mas principalmente o impreciso conceito de identidade, já pressuposto na figura inusitada de um narrador-personagem que não é nada mais, nada menos do que uma osga. Assim, ao escolher uma osga (espécie de lagartixa, que desempenha papel fundamental nessa discussão), o autor sugere um olhar isento de qualquer envolvimento do narrador com a essência demasiadamente humana da questão da identidade: enquanto ser irracional, deplacé, a osga está, supostamente, imune às questões "existencialistas" inscritas na trajetória dos demais personagens, a despeito de, inesperadamente, o enredo sugerir que ela teria sido, anteriormente (em outra vida?) um ser humano, carregando portanto consigo traços de uma angústia existencial, ora de alguém inutilmente à procura por um interlocutor, ora de alguém dotado de um humano remorso por não ter amado.

Assim, a cada passo da história, desdobra-se uma infinidade de possibilidades reflexivas, tornando $O$ Vendedor de Passados quase um romance filosófico, quando não existencialista, em que a identidade afirma-se como jogo de imagens refletidas em infinitos espelhos, tornando-se, portanto, um simulacro da realidade e fazendo confundirem-se verdade e mentira, fato e ficção, essência e aparência, ser e não-ser...

Se, como diz uma personagem, "a verdade é improvável”, a fábula passa a ocupar o lugar da realidade, fazendo com que tudo se relativize e com que os pólos, aparentemente díspares, se atraiam e se igualem: "eu dou-lhe uma verdade impossível, você dá-me uma mentira vulgar e convincente". (AGUALUSA, 2004, p. 185). 


\section{Moçambique}

Embora buscando soluções próprias para as questões culturais locais, o que resulta em produções singularizadas, a literatura moçambicana apresenta um percurso parecido com a de Angola, em razão dos contatos entre os dois povos, o intercâmbio cultural e, principalmente, a língua portuguesa.

Podendo ser dividida, didaticamente, em cinco fases distintas, conheceu, numa primeira fase de formação (1920-1940) uma produção em que a mestiçagem cultural (africanos e portugueses) prevaleceu, tendo sido produzida por profissionais liberais que procuravam, a seu modo, fazer representar a cultura africana nativa na literatura. São autores, entre outros, como João Albasini, Augusto de Conrado ou Rui de Noronha, poeta maior desse período que, nos dizeres de Patrick Chabal, "mostra sensibilidade para com a situação crítica dos mestiços e negros no contexto colonial, e é, em parte, uma chamada de atenção para o acordar da excessivamente passiva África”. (CHABAL, 1994, p. 42).

Uma segunda fase, a que podemos chamar de pré-independente (1940-1960), caracteriza-se, antes, pela motivação política, a despeito da manutenção de evidente influência europeia. Fase de predominância da poesia, notabilizou-se pela presença de autores consagrados, como Alberto de Lacerda, Antonio Quadros, Rui Nogar e Rui Knopfli.

A chamada literatura revolucionária (1960-1980), mais próxima de nossos dias, revela autêntico ímpeto nacionalista, além de privilegiar a temática independentista, a exemplo do que acontecia em outras nações africanas. Tendo como fundamentação ideológica questões de natureza político-social, trata-se de uma produção em que se destacaram nomes célebres como os de Luís Bernardo Honwana, Marcelino dos Santos/Kalungano, Sérgio Vieira, Albino Magaia e Jorge Rebelo. Ainda nos dizerem de Patrick Chabal,

de um ponto de vista histórico, esta literatura fornece elementos sobre o processo pelo qual os moçambicanos forjaram a consciência nacionalista e ou revolucionária. Oferece um comentário político e social acerca das questões mais candentes do período em que foi escrita. (CHABAL, 1994, p. 55)

Uma fase a que se pode nomear independente (1980-1990) já revela pleno sentido de moçambicanidade, com a valorização da independência (em Moçambique, datada de 1975) e o apego a valores nacionais. Pode ser, finalmente, representada por autores como Orlando Mendes, Sebastião Alba, Heliodoro Batista e, sobretudo, José Craveirinha, o grande autor da moçambicanidade.

Finalmente, a literatura contemporânea (1990-2000) notabiliza-se pela confecção de uma prosa mais intimista, bem como pela valorização da literatura popular e, ao mesmo 
tempo, a superação da perspectiva político-ideológica. Tendo sido magistralmente representada por autores como Paulina Chiziane, Ungulani Khosa, Elton Rebello, Suleiman Cassano e outros, tem na figura de Mia Couto um dos escritores mais conhecidos e festejados da atual literatura em língua portuguesa, sendo ainda um autor - ao lado de outros - em que a regeneração dos valores culturais do moçambicano, destruídos pelo colonialismo europeu, passa por um contínuo exercício de subversão do português. (AFOLABI, 1997).

Dois são os autores que, na literatura moçambicana, destacaram-se por escrever uma prosa carregada de significados sociais e simbólicos, representando, cada um à sua maneira, as duas principais fases de sua literatura: Luís Bernardo Honwana e Mia Couto.

Buscando analisar a produção literária africana pós-colonialista, a crítico e escritor angolano Costa Andrade advoga a existência de três grandes linhas de orientação dessa ficção: a tradicionalista, ligada aos rituais religiosos tradicionais, ao fantástico e ao sobrenatural, além de valorizar culturas populares; a do realismo introverso, composta por obras que retratam conflitos íntimos, de fundo psicológico; e a do realismo social, cuja obras exprimem uma relação entre colonizador e colonizado, o novo e o velho, a opressão e a liberdade, em geral sob a ótica da violência, quase sempre exprimindo-se como uma literatura engajada. A essa última linhagem pertenceria a produção - ao lado de Castro Soromenho, Luandino Vieira, Manuel Ferreira e outros - de Luís Bernardo Honwana. (ANDRADE, 1980).

Natural de Lourenço Marques, atual Maputo (capital de Moçambique), Luís Bernardo Honwana cresceu numa pequena cidade do interior, Moamba, tendo retornado, mais tarde, à capital para estudar. Ainda jovem, dedicou-se ao jornalismo, destacando-se também na produção literária independente. Militante anticolonialista, foi preso em 1964, ano em que publicou seu livro mais conhecido: Nós Matamos o Cão-Tinhoso. Adotado nas escolas, presente em antologias, traduzido para dezenas de idiomas, trata-se de uma antologia de contos que pode ser considerada uma das mais contundentes produções da literatura lusófona contemporânea.

Com efeito, em Nós Matamos o Cão-Tinhoso, prevalece a mescla entre a narrativa introspectiva e a temática de cunho social, fazendo com que as reflexões acerca da existência humana nasçam da aguda observação da realidade circundante e suas distorções sociais. Trata-se de uma narrativa com um estilo próximo da oralidade e da linguagem cotidiana, onde se misturam o poético e o prosaico. Lidando com assuntos do dia a dia, mas por meio de um olhar criticamente incisivo, Honwana leva seus temas e motivos literários ao limite da dramatização, resultando, vez por outra, como aliás já era de se esperar, pelo tom de sua 
narrativa, numa concepção pessimista da realidade. Alguns temas, contudo, sempre tratados num estilo objetivo e direto, próximo do relato, são recorrentes, como é o caso do conflito racial que, no instante em que o livro fora escrito, estava particularmente na ordem do dia, o que levou o crítico Russel Hamilton a definir essa obra como uma particular "ficção racial". (HAMILTON, 1981, p. 32).

Mia Couto (né António Emílio Leite Couto) é, atualmente, o autor com maior visibilidade no universo das letras africanas lusófonas. Natural da cidade da Beira, costuma ser comparado a outro grande autor da Língua Portuguesa do século XX, o escritor brasileiro João Guimarães Rosa, tanto por tratar de questões relacionadas à vida cotidiana, no caso de Moçambique, quanto pela inventividade de sua escrita, numa permanente descoberta de novas palavras, por meio de um processo de cruzamento entre o português culto e os vários registros linguísticos empregados pela população comum, num inusitado processo de criação, apropriação e renovação do português. A vida do povo moçambicano e sua cultura de modo geral estão representados em sua extensa obra ficcional, onde não faltam o humor e o trágico, a incorporação da linguagem cotidiana, a inclusão do fantástico e do imaginário, tudo veiculado por meio de uma escrita em que se destaca, como assinalamos há pouco, um intenso trabalho de criatividade linguística.

Traduzido e premiado no mundo todo, Mia Couto estreou na literatura com o livro de poesia Raiz de Orvalho (1983), para logo passar aos dois gêneros ficcionais que o consagraram: o conto (com Vozes Anoitecidas, 1986; Cada Homem é uma Raça, 1990; Estórias Abensonhadas, 1994; Contos do Nascer da Terra, 1997; Na Berma de Nenhuma Estrada, 1999; O Fio das Missangas, 2003 etc.); e o romance (com Terra Sonâmbula, 1992; A Varanda do Frangipani, 1996; O Último Voo do Flamingo, 2000; Um Rio Chamado Tempo, uma Casa Chamada Terra, 2002; O Outro Pé da Sereia, 2006; Venenos de Deus, Remédios do Diabo, 2008 etc.).

Nos contos de Cada Homem é uma Raça (1990), por exemplo, percebe-se - do ponto de vista estilístico - o trabalho de recriação linguística tanto por meio da transgressão gramatical quanto pela intensa atividade ligada à neologia (com a invenção de vocábulos como sobressonhava, esroupada, desconsegui, imovente, malditar, desorfanava, matabichávamos, consequenciaria, panicar pontapesaria, lacrimaruja, pernação, senfins, invindável, desmarado e outras). Com narrativas marcadas por conflitos intimistas ("Rosa Caramela"), com trechos narrativos carregados de sentido existencial e desdobramentos poéticos, com o emprego constante de metáforas filosóficas, seus contos lembram, às vezes, pelo fluxo intimista e existencialista, algumas histórias de Clarice Lispector. Nem por isso, o 
tema social deixa de estar presente em sua produção, e mais uma vez é a questão racial que acaba imperando (“A princesa russa”), sem dispensar, contudo, a linguagem poética, carregada de metáforas e imagens subjetivas.

Em A Varanda do Frangipani (1996), um dos mais consagrados romances de Mia couto, destacam temas como o conflito entre a tradição nativa africana e a tradição portuguesa, bem como entre o passado - representado pela tradição - e o presente representando a modernidade. Trabalhando com ciclos distintos (começa com um morto, figurando um ciclo que se fecha; passa ao retorno desse morto à vida, simbolizando um ciclo que se abre; para, finalmente, voltar à condição de morto, num ciclo que volta a se fechar), trata-se de uma narrativa particularmente marcada pelo jogo de identidades (Ermelindo Mucanga / Izidine Naíta), em que não se dispensa uma reflexão sobre o problema da desterritorilização (como no caso de Domingos Mourão / Xidimingo).

A palavra, sobretudo a palavra falada, exerce uma função mítica na história, como ocorre com Navaia Caetano - para quem as pessoas no asilo "vivemos muito oralmente" (COUTO, 2007, p.26) -, que pede a Izidine Naíta/Ermelindo Mucanga que não escrevesse nada, apenas escutasse sua história. Da mesma forma, a fala, o contar, representa, muitas vezes, uma sentença de morte, além de ser um perigo tanto a quem fala quanto a quem ouve. A questão da linguagem tem ainda um sentido especial na figura da feiticeira Nãozinha, para quem a palavra possui um valor sobrenatural.

Resgatando o universo cultural e místico do continente africano, em particular da sociedade moçambicana, a narrativa é contada em primeira pessoa, num nítido esforço introspectivo, embora esse fato não prescinda de uma troca de narrador que resulta na construção de histórias dentro da história, gerando, entre outras coisas, um sentido amplo de instabilidade ontológica: "na vida, só a morte é exacta. O resto balança nas duas margens da dúvida". (COUTO, 2007, p. 136)

O Último Vôo do Flamingo (2000) tem no humor uma de suas características mais marcantes, fato que nasce, entre outras coisas, de situações inesperadas, quando não do nonsense. Há, evidentemente, um conflito entre o mundo europeu (aqui representado pelo italiano Massimo Risi) e o africano (representado pelo narrador), tema sempre presente em Mia Couto, mas tratado de modo mais seguro, sem alguns ranços militantes que, eventualmente, poderiam empanar a narrativa.

Autor refinado, tanto no trato da composição quanto no da linguagem, Mia Couto não abandona as tradições populares de seu povo, buscando sempre contemplar - mas agora de forma mais criativa e ousada, obtendo assim maior efeito estético - aquela moçambicanidade 
sempre buscada desde os primeiro autores daquela região. Dele, portanto, disse Patrick Chabal com propriedade:

por um lado, Mia Couto reflecte no seu trabalho a diversidade do discurso popular. Explora as subtilezas do português moçambicano, falado actualmente em Moçambique, que é distincto do português de Portugal. Enquanto muitos outros escritores moçambicanos ainda usam o português 'clássico', relativamente neutro, Mia Couto está na vanguarda dos que tentam integrar o português de Moçambique na sua escrita. (CHABAL, 1994, p. 68).

Como se percebe, a literatura moçambicana não poderia estar mais bem representada com a ficção universal de Mia Couto.

\section{Cabo Verde}

Cabo Verde possui uma literatura variada, em que a cultura popular - em geral, representada pela tradição lírica advinda das mornas, cantigas populares próprias da região -, a questão da diáspora africana, os conflitos sociais e o tradicional embate racial entre brancos e negros não estão ausentes. Tudo isso pode tanto ser percebido na poesia de um Aguinaldo Fonseca, um Arménio Vieira, um Corsino Fortes, quando na prosa engajada de um Manuel Ferreira.

Em Hora di Bai (1962), romance social de Manuel Ferreira, temas como o deslocamento migratório ou a estiagem assinalam o vínculo de sua literatura para com o neorrealismo português e a segunda geração modernista do Brasil, sem deixar, contudo, de apresentar uma solução própria para as contradições presentes na sociedade caboverdiana. Empregando ora o discurso indireto, ora o discurso indireto livre, seu estilo assenta-se no fecundo recurso da oralidade, buscando dar voz às minorias desfavorecidas e fazendo da resistência política e social o motor de sua narrativa.

Diferente na concepção, na proposta e no resultado é o romance $O$ Testamento do Sr. Napumoceno (1996) de Germano Almeida, história de Napumoceno da Silva Araújo, “comerciante de importação e exportação, armazéns de venda a grosso" (ALMEIDA, 1996, p. 18) que, ao falecer, deixa a seu sobrinho - Carlos Araújo - em extenso testamento, uma ínfima parte de seus bens materiais. Ao longo do testamento, várias passagens da vida de Napumoceno vão sendo reveladas: sua paixão arrebatadora por Adélia, sua indisposição para com o sobrinho, sua sociedade com Ramires, a revelação de uma filha natural (Maria da Graça), fato que até a data de sua morte mantivera em segredo etc.

Escrito num tom que vai do solene e testamentário ao coloquial, o romance apresenta - do ponto de vista do discurso narrativo - uma mescla entre o discurso indireto e o indireto livre, passando naturalmente de um para o outro. Trata-se, não obstante, de uma narrativa 
linear, com poucas pausas, com discursos que se misturam e diálogos que se sobrepõem, dando-lhe certo dinamismo. O estilo é ligeiro, sem interrupções, como se proviesse de um fluxo de consciência atípico, porque regrado e lúcido. Nesse ritmo, que não chega a ser alucinante por falta de maior ousadia do autor, passado e presente se sucedem, num constante e ininterrupto enredamento de vidas, histórias, lembranças que, no conjunto, forma o painel matizado - e, muitas vezes, engraçado - da vida comum de um comerciante local.

Narrativa polifônica, contém personagens que assumem o papel de vários narradores, cujas lembranças, opiniões e testemunhos vão formando um quadro da vida de Napumoceno, e tudo em torno de um eixo narrativo representado pelo testamento, que, aliás, parece conter não propriamente ocorrências prosaicas do dia-a-dia de Napumoceno, mas refletir certo tumulto interior e uma existência um tanto pragmática, embora com laivos de visionarismo. Curiosamente, conforme a trama progride, a narrativa vai adquirindo um tom cada vez mais intimista, de tal modo que, ao final do romance, temos uma idéia quase completa do perfil psicológico de Napumoceno, comerciante movido por uma lógica mercantilista que, não raro, beirava às raias do absurdo.

\section{Conclusão}

O panorama literário aqui apresentado demonstra bem a importância da literatura africana de expressão portuguesa atualmente. É por meio de textos e autores com as mais variadas propostas estéticas que se constrói o legado literário das nações lusófonas. Evidentemente, essa produção é mais bem compreendida no contexto em que se insere, mas, sem dúvida alguma, trata-se de uma literatura que tem um alcance universal, que ultrapassa os limites do continente africano e da própria língua portuguesa.

Não devemos nos esquecer, além disso, que essa literatura estabelece laços inquebrantáveis com a realidade sociocultural brasileira, sendo seu estudo particularmente propício à compreensão de nossa própria produção literária, caudatária, de certo modo, da cultura de matriz africana e de suas manifestações linguísticas.

Essa valorização do legado cultural africano, aliás, já vem se realizando, aos poucos, por força da lei 10.639, de 2003, por meio da qual ensino da história e da cultura africana e afro-brasileira não apenas torna mais eficaz o acesso dos estudantes a informações preciosas acerca de nossa formação cultural, mas também possibilita a compreensão - que leva à consciência - da formação social brasileira. A referida lei é, sem dúvida, uma prática institucional de inclusão e de ação afirmativa, ao mesmo tempo em que representa o resultado de um intenso movimento de luta antirracista no Brasil, (SANTOS, 2005, p. 24) destacando- 
se por sua capacidade multiplicadora, na medida em que pode gerar uma série de iniciativas voltadas para a valorização da cultura afro-brasileira, bem como servir de estímulo à reconstrução da identidade afro-descendente. Trata-se, em outros termos, de uma lei voltada ao resgate da auto-estima, dos valores culturais, dos direitos, da memória e da identidade do negro, desfazendo equívocos seculares e ressemantizando o conceito de negro dentro do complexo sócio-etnográfico nacional:

a palavra negro expressa a noção de identidade assumida e, ao mesmo tempo, procura subverter os significados negativos associados a ela desde o período escravista. Em conseqüência disso, ser negro consiste em preservar o orgulho de pertencer a um grupo étnico cujos membros sobreviveram à exploração escravista e trabalharam para participar da vida social do país. (PEREIRA \& WHITE, 2001, p. 259).

Portanto, passa a ser papel de todo educador a luta incondicional pela superação do racismo e da discriminação racial, e a lei 10.639 talvez seja um dos caminhos mais eficazes para que esse ideal possa ser alcançado.

Além dessa questão pedagógica, por assim dizer, estudar as manifestações literárias africanas pressupõe ainda a elaboração de uma ampla reflexão sobre a questão do nacionalismo e da identidade na literatura, conceitos largamente presentes nos autores e obras aqui citados, bem como na maior parte da produção literária africana mais recente. Desse modo, nacionalismo e identidade acabam sendo noções que, embora em contínua transformação, aparecem problematizados na representação literária dos países estudados, via de regra associando-se a um claro pendor militante e engajado, apesar de presentes também numa expressão mais larga, de cunho existencialista e introspectivo. (LARANJEIRA, 1997) Isso, evidentemente, sem se esquecer dos experimentalismos formais e do trabalho minucioso que se tem feito com a linguagem, a qual passa a representar, na produção mais recente, uma etapa de superação de seu viés marcadamente ideológico. (HAMILTON, 1981).

Esse é, portanto, um percurso ideológico de muitas faces, mas no qual se afirmam pelo menos duas idéias recorrentes: o imperativo moral e o imperativo estético.

O primeiro provém da tese, defendida por Sartre, de que a literatura volta-se, entre outras coisas, para a defesa de valores sociais da humanidade, associando-se, assim, à prática libertária, seja ela relacionada ao autor, ao leitor ou à sociedade como um todo. Nesse sentido, a literatura - e esta é uma correlação bastante apropriada à literatura africana lusófona traduz-se numa tomada de posição daqueles que com ela estejam diretamente envolvidos. (SARTRE, 1989) O segundo provém das idéias expostas por Marcuse, segundo as quais a arte se manifestaria em meio às relações sociais e possuiria um potencial político, mas, ao contrário da ortodoxia marxista, ele estaria contido nela mesma, na sua dimensão estética, 
concorrendo, dessa forma, para a defesa da liberdade. (MARCUSE, 1981)

Em ambas as teorias, a arte - exatamente como tem ocorrido nos melhores exemplos da produção lusófona em África - estaria visceralmente relacionada à idéia de liberdade, mas enquanto para Sartre ela se revela como um imperativo moral, para Marcuse, ela se manifesta como um imperativo estético.

De qualquer maneira, podemos dizer sem exagero que a literatura africana lusófona como as melhores manifestações literárias conhecidas - se opõe visceralmente ao imaginário negativo de que o continente africano foi sempre vítima, resgatando o que o povo africano tem de melhor a oferecer: sua cultura, suas crenças, sua personalidade, seu imaginário, tudo transformado na mais sublime matéria artística. Para que percebamos esse fato, basta que saibamos ver a realidade tal e qual ela se nos apresenta, destituídos de qualquer preconceito e estereótipo. Pois. como afirmou o angolano Pepepela, em seu magistral romance, A Geração da Utopia, "os raios de sol sempre descobrem as faces escondidas do diamante, mesmo se enterrado na areia. É só preciso saber ver". (PEPETELA. 2000, p.101).

\section{Referências}

AFOLABI, Niyi. "Uma Gaiola de Ouro: A Problemática da Regeneração na Literatura Africana de Língua Portuguesa". África. Revista do Centro de Estudos Africanos. Universidade de São Paulo, São Paulo, No. 20-21: 27-41, 1997.

AGUALUSA, José Eduardo. Um Estranho em Goa. Rio de Janeiro, Gryphus, 2001.

. O Ano em que Zumbi tomou o Rio. Rio de Janeiro, Gryphus, 2002.

. O Vendedor de Passados. São Paulo, Companhia das Letras, 2004.

ALMEIDA, Germano. O Testamento do Sr. Napumoceno. São Paulo, Companhia das Letras, 1996.

ANDRADE, Costa. Literatura Angolana (Opiniões). Lisboa, Edições 70, 1980.

CHABAL, Patrick. Vozes Moçambicanas. Literatura e Nacionalidade. Lisboa, Veja, 1994.

COUTO, Mia. A Varanda de Frangipani. São Paulo, Companhia das Letras, 2007.

HAMILTON, Russel G. Literatura Africana. Literatura Necessária. Lisboa, Edições 70, 1981.

LARANJEIRA, Pires. Literatura Calibanesca. Porto, Afrontamento, 1985.

"Língua e Literatura nos Países Africanos de Língua Oficial Portuguesa". In: GALANO, Ana Maria et alii (orgs.). Língua Mar: Criações e Confrontos em Português. Rio de Janeiro, Funarte, 1997, p. 83-99.

"As Literaturas Africanas de Língua Portuguesa - Identidade e Autonomia" Scripta, Belo 
Horizonte, Vol. 03, No. 06: 237-244, 2000.

MARCUSE, Herbert. A Dimensão Estética. São Paulo, Martins Fontes, 1981.

PEPETELA. A Geração da Utopia. Rio de Janeiro, Nova Fronteira, 2000.

PEREIRA, Edimilson de Almeida e WHITE, Steven F. "Brasil: Panorama de Interações e Conflitos numa Sociedade Multicultural". Afro-Ásia. Centro de Estudos Afro-Orientais/Universidade Federal da Bahia, Salvador, No. 25/26: 257-280, 2001.

RETAMAR, Roberto Fernández. "Intercomunicação e Nova Literatura". In: MORENO, César Fernández (coord.). A America Latina em sua Literatura. São Paulo, Perspectiva, 1979, p. 325339.

SANTILLI, Maria Aparecida. Estórias Africanas. História e Antologia. São Paulo, Ática, 1985a.

Africanidade. Contornos Literários. São Paulo, Ática, 1985b.

SANTOS, Francisca Maria dos. Quarup e A Geração da Utopia: História - Ficção e Utopia. São Paulo, FFLCH/USP, 2001 (Dissertação de Mestrado).

SANTOS, Sales Augusto dos. "A Lei 10.639/03 como Fruto da Luta Anti-Racista do Movimento Negro". In: MINISTÉRIO DA EDUCAÇÃO, SECRETARIA DE EDUCAÇÃO CONTINUADA, ALFABETIZAÇÃO E DIVERSIDADE. Educação Anti-Racista: Caminhos Abertos pela Lei Federal n ${ }^{\circ}$ 10.639/03. Brasília, 2005, p. 21-37.

SARTRE, Jean-Paul. Que é Literatura? São Paulo, Ática, 1989.

SILVA, Maurício. "A Tradição da Transgressão: Língua Portuguesa e a Identidade Cultural em Luandino Vieira". Scripta, Pontifícia Universidade Católica de Minas Gerais, Belo Horizonte, V. 11, No. 20: 167-176, 2007. 